\title{
Implantátumok szubstruktúrájának illeszkedési lehetőségei az endostruktúrához
}

\author{
Irodalmi áttekintés
}

\author{
DR. KERKOVITS BÁLINT, DR. CZINKÓCZKY BÉLA, DR. KIVOVICS MÁRTON
}

\begin{abstract}
Az implantátum és implantátumfejek illeszkedési módjai folyamatos változáson mennek keresztül, mégis kevés friss magyar irodalmat találhatunk ebben a témában. A piacon megtalálható rengeteg féle kapcsolatot különböző aspektusokat figyelembe véve hasonlítjuk össze, ami segíthet az adott indikációban megfelelö kapcsolattípus kiválasztásában. Brånemark eredeti, külső hatszöges implantátuma kiváló alternatíva a fogatlan páciensek ellátására. Az indikációk kiszélesedésével azonban szükséges lett a hagyományos külső hatszög-konstrukció módosítása, illetve a belső kapcsolatok kifejlesztése. Az új indikációkban jelentkező csavarlazulás és törés fokozott incidenciáját így sikerült csökkenteni. A külső kapcsolatok mikromozgása jelentős, és mikrorések is gyakrabban fordulnak elő a komponensek között, így bakteriális zárásuk kevésbé kielégító. A legjobb mechanikai és biológiai zárást a kúpos struktúrákkal lehet elérni, azonban nem rendelkeznek elfordulásgátló tulajdonsággal. A sokszöget vagy hornyot tartalmazó struktúrák rendkívül előnyösek szóló foghiányok pótlása esetén, vagy szögtört implantátumfejek alkalmazásakor. A belső kapcsolatok erőeloszlása a csavarra és az implantátumra nézve kedvezőbb, viszont a csont nagyobb terhelésben részesül, mint a külső kapcsolatoknál, így ezt is mérlegelnünk kell, mikor választásra kerül a sor. Esztétikai szempontból a belső kapcsolatok sokkal kedvezőbb eredményt nyújtanak.
\end{abstract}

Kulcsszavak: implantátum, szubstruktúra, implantátumfej, mikromozgás, esztétika

\section{Bevezetés}

A fogászati implantációs rendszerek gyors fejlődésével a gyakorló fogorvosoknak nehéz lépést tartani. Az implantáció sebészi kérdései nagyrészt tisztázottak, közeli mútéttani forradalom nem várható. Az implantátum és implantátumfejek kapcsolódási módjai azonban folyamatos változáson mennek keresztül, mégis kevés friss magyar irodalmat találhatunk az implantológia ezen oldaláról.

A cikkben részletesen taglaljuk a különböző típusú implantátumfejek legfontosabb kapcsolati módjait a kompatibilis implantátumokkal. A piacon megtalálható rengeteg féle kapcsolatot különböző aspektusokat figyelembe véve hasonlítjuk össze. Leírjuk előnyeiket, hátrányaikat biológiai, mechanikai és esztétikai szempontokból. Tanulmányozásuk segíthet a gyakorlatban eldönteni, hogy általánosságban, illetve az adott indikációt tekintve melyik az ideális kapcsolattípus egy-egy foghiány ellátására.

\section{Implantátum-implantátumfej kapcsolatok}

Attól függően, hogy az implantátumfej hogyan rögzül az implantátumhoz, megkülönböztethetünk külső és belső kapcsolatot. Ezen csoportokon belül a kapcsolódó részek formai kialakítása szerint lehet tovább sorolni az implantátum-implantátumfej kapcsolatokat.

\section{Külső kapcsolatok}

Külső kapcsolatos implantátumoknál az endostruktúra feji részén megfigyelhető annak meghosszabbítása valamilyen geometriai alakzat formájában. Az implantátumfej erre kívülről illeszkedik rá, majd egy átmenő csavarral rögzül hozzá.

\section{Külső hatszöges (External Hex)}

- Southern Implants

A külső hatszöges történelmileg az első implantátumfelépítmény kapcsolat, amely mögött a legtöbb szakmai tapasztalat áll. Brånemark eredeti implantátumán a hatszög formájú nyúlvány magassága $0,7 \mathrm{~mm}$ volt. Az általa kifejlesztett protokoll a teljes fogatlan páciensek ellátására korlátozódott, és ebben az esetben merev öntvény fogta össze az implantátumokat, így kevés szövődmény jelentkezett. Az esztétikával szemben a funkció, az osszeointegráció végbemenetele és a biztonság prioritást élvezett [4, 30].

Mára az indikációk jelentősen kiszélesedtek, részleges foghiányok, szóló pótlások, maxillofaciális sebészeti alkalmazások, melyek kivitelezésének csak az orvos kompetenciái szabnak határt [29]. Ezen indikációkban a Brånemark-féle külső hatszöges implantátum használata jelentős klinikai komplikációi miatt alkalmatlan [13]. A vizsgálatok rámutattak, hogy szignifikáns számú eset- 
ben jelentkezik csavarlazulás, törés, illetve az érintkező felszínek között mikromozgás [26]. A mikromozgás csökkentésére próbálkoztak a hatszög átmérőjének és a nyúlvány magasságának növelésével, de a stabilitásban ez sem hozott kiemelkedő eredményeket.

Ezen nehézségek, illetve a cementezhető pótlás megjelenése új irányokba terelték a kapcsolóstruktúrák fejlődését [4, 10].

\section{Kúpos hatszöges (Tapered Hexagon)}

- Zimmer Dental - Paragon implantátum

A kúpos hexagont először a Swede-Vent TL (Paragon Implant) fejlesztette ki. Ez a kialakítás az implantátum és az implantátumfej közti illeszkedés javítását célozta meg. A hagyományos külső hexagonális érintkezést annyiból változtatták meg, hogy a hatszög alapú pátrix falait 1,5-os konvergenciával képezték ki, és ehhez súrlódást kihasználva szorosan illeszkedő vájatot alakítottak ki az implantátumfejben. Ezzel jelentősen redukálódik az elfordulás a két komponens közt, ami a csavarlazulás csökkenését is magával vonja. Van olyan kutatás, amely a mikromozgás megszúnéséről számol be [3].

\section{Külsó nyolcszöges (External Octagon)}

- Straumann - Standard Plus Narrow Neck

A külső nyolcszöges kialakítású implantátum először a Straumann cég által lett piacra dobva (Standard Plus Narrow Neck-3,3 mm), kifejezetten egy fog pótlására szolgáló, szúk helyre (alsó frontfogak, és felső kismetszők helyére) csavarható, keskeny nyakú implantátumként. A magas, nyolcszög alakú nyúlványból adódóan több helyzetben rögzíthető a felépítmény, mint a hatszög formánál. Ez az implantátum nem használható szögtört implantátumfejekkel, ráadásul a külső nyolcszöges kapcsolat nem biztosít megfelelő elfordulási ellenállást [7, 30]. Ezen hátrányok kiküszöbölése végett a gyártó kifejlesztette a CrossFit kapcsolatot Narrow Neck implantátumaihoz.

\section{Hornyos kapcsolat (Spline Dental Implantátum) \\ - Calcitek - Spline Technology}

Ezt a rendszert a Calcitek fejlesztette ki, a tradicionális hatszög struktúrát továbbgondolva, mégpedig úgy, hogy a hatszög csúcsai helyén hornyok vannak, amikbe az implantátumfej nyúlványai illeszkednek, a hatszög oldalai pedig az implantátumfejen lévő mélyedésekbe süllyednek bele. Így tökéletes illeszkedést lehet elérni kiváló behelyezési pontossággal. Ez az implantátum 4, 5 és 3,5 mm-es átmérővel elérhető.

A 4 és $5 \mathrm{~mm}$ átmérőjű implantátumok mechanikailag stabilak, és a csavarlazulásnak, illetve a fej elfordulásának is kisebb az előfordulási valószínúsége, mint a hagyományos hexagonális kapcsolatnál [5].

\section{Belsö kapcsolatok}

A külső kapcsolatos struktúráknál tapasztalható komplikációk kiküszöbölésére megalkották a belső kapcsolat- tal rendelkező implantátum rendszereket. Ezekben az esetekben a pátrixként funkcionáló geometriai struktúra az implantátumfejen van, és az illeszkedik az implantátum koronális részén elhelyezkedő mélyedésbe. Az új modellek megalkotásának célja a kapcsolat stabilitásának növelése volt, mind funkcióban, mind behelyezéskor. Ugyanakkor az orvos feladatának megkönnyítése is fontos volt a rendszerek egyszerüsítésével, egységesítésével.

Általános jellemzőjük, hogy a protetikai tartozékoknak kisebb hely szükséges vertikálisan, a laterális terhelés az implantátum belsejében oszlik el. A csavar az implantátum belsejében védve, a fejjel és a hosszú belső fallal tömör, a kapcsolat lazulásának ellenálló egységet alkotva helyezkedik el. Az implantátummal való szoros kapcsolat tompítja a rezgéseket, ami a mikrobiális szivárgás egyik melegágya. További előny, hogy növeli a rugalmasságot, és lehetővé teszi a restauratív komponensek határvonalát az implantátum szintjéhez közelíteni, ami esztétikailag kedvezőbb [4].

\section{A 3 pontos belső háromszög (3-point internal tripod) \\ - Nobel Biocare - Replace Select}

Ez a típusú implantátum-felépítmény kapcsolat belső háromszöges geometriát képvisel. A rendszer legfőbb hátránya, hogy csak 3 pozíciót engedélyez az implantátumfejnek (120-os szögeltérésenként). Ezt a koncepciót a Nobel Biocare mutatta be Replace Select rendszer néven. A behelyezési pozíciók limitált száma miatt ugyanakkor klinikailag nem annyira közkedvelt [30]. Ráadásul, összehasonlítva a külső hatszöges kapcsolattal, a feszültségeloszlása is kedvezőtlenebb az axiális tengelytől eltérő terheléseknél. Összességében nem tekinthető kedvező struktúrának [19].

\section{A 6 pontos belső hatszög (6-point internal hex) \\ - DenTi, Zimmer Dental, Blue Sky Bio, \\ Southern Implants}

Ez a forgalomban levő legszéleskörübben használt belső kapcsolat. Az implantátumfejen lévő hatszög süllyed bele az endostruktúrában kialakított mélyedésbe. Ez a struktúra a felépítménynek hat különböző fix pozíciót engedélyez ( $60^{\circ}$-os szögeltérésekkel).

Léteznek a belső hatszögnek módosított változatai. Van, ahol cilindrikus struktúrával van kombinálva, így nagyobb az ellenállása a laterális terhelések tekintetében (1. kép). Egy másik rendszerben egy lépcsőscilindrikus komponenssel egészül ki, amely nem csak a laterális, de az axiális irányú terhelésnek is jobban ellenáll.

\section{Belső nyolcszög (Internal octagon) \\ - Calcitek - Omniloc}

Ebben az esetben a kapcsoló struktúrát nyolcszöges geometria biztosítja. Ez 8 különböző pozíciójú rögzítést eredményezhet. Az első belső nyolcszöges kapcsolatot a Calcitek mutatta be, Omniloc rendszer néven. A keskeny oldalfalak és a nyolcszögletű kialakítás nem biztosított kellő ellenállást sem az elfordulás, sem a laterális 
terhelések ellen, ezért ez a rendszer már nincs forgalomban [4].

\section{A 12 pontos belsö hatszög (12-point internal hex) - Biomet $3 i$}

A 12 pontos belső hexagon, vagy más néven az eltolt hexagon kialakítás nagyobb szabadságot biztosít az implantátumfej helyzetével kapcsolatban. Ebben az esetben 12 pozícióban (30 fokonként) lehet behelyezni. Ez különösen hasznos szögtört implantátumfejek alkalmazásakor, sokkal több lehetőséggel szolgál a szögeltérések pontos kiküszöbölésére [30]. Véges elemes modellanalízis kimutatta, hogy a 6 pontos és 12 pontos belső hatszöges rendszerekben jobban oszlik el a feszültség, és az elmozdulás is kisebb mértékű, mint a $45^{\circ}$-os kónusszal kombinált belső hatszöges, illetve a Brånemark féle hagyományos külső hatszöges konstrukciókban [33].

\section{Kúpos (Morse Taper) kapcsolatok}

Ebben a koncepcióban az implantátumfejen lévő kúp csúszik bele az endostruktúrában kialakított üregbe, így súrlódási illeszkedés (friction-fit) és az alkotórészek szoros összepréselődése (cold welding) jön létre az érintkező felszíneken. Ezek a jelenségek döntően meghatározzák a kapcsolódó struktúrák közti elfordulás kiküszöbölését, illetve megelőzik a csavarlazulást.

A kónuszos kapcsolat olyan optimális tulajdonságokat tudhat magáénak, mint a felépítmény kiszámítható vertikális elhelyezése és az önzáró (self-locking) mechanizmus. Az implantátumfej implantátumhoz való préselődése jelentősen megnöveli a rendszer hajlító erőkkel szembeni ellenállását. Tanulmányok kimutatták, hogy egyes komplikációk, például a csavarlazulás gyakorisága is szignifikánsan csökkent a külső hatszöges kapcsolatokhoz képest [27].

Az eredeti „Morse Taper” két kúpot tartalmazott: egy $2^{\circ}$-os és egy $4^{\circ}$-os biztosította a precíz illeszkedést, akkor még az önzáró koncepció nélkül. Később több fajtája is megjelent a piacon.

A $8^{\circ}$-os Morse-kúppal kapcsolódó implantátumfej mögötti elméleti elgondolás az volt, hogy a kónuszos struktúra egy mechanikailag stabil, megbízható és önzáró illeszkedést biztosít. Az alapját a gépiparban alkalmazott „Morse Taper” koncepció jelentette, innen került át a fogászatba [9].

Az ITI-Straumann cég tovább módosította ezt a kapcsolatot, így fejlesztette ki a ma is forgalomban lévő Synocta rendszert. Az eredeti kúpos megoldás miatt a precíz illeszkedés adott volt annak minden elónyével, ugyanakkor az implantátumfejnek nem volt fix pozíciója az endostruktúrában. Ennek tökéletesítésére a kúpot egy belső nyolcszöggel egészítették ki, ezáltal az implantátumfej kicsavarás után újra visszahelyezhető ugyanabba a pozícióba, így az a mestermintára is pontosabban átvihető. Kétrészes, az átmenő csavar meghúzása után megbízható rögzítettséget ad. Tehát ezzel a lépéssel a protetikai rendszer is egyszerübbé vált, egy átvivő technika és egy laboranalóg szükséges a fogtechnikus-

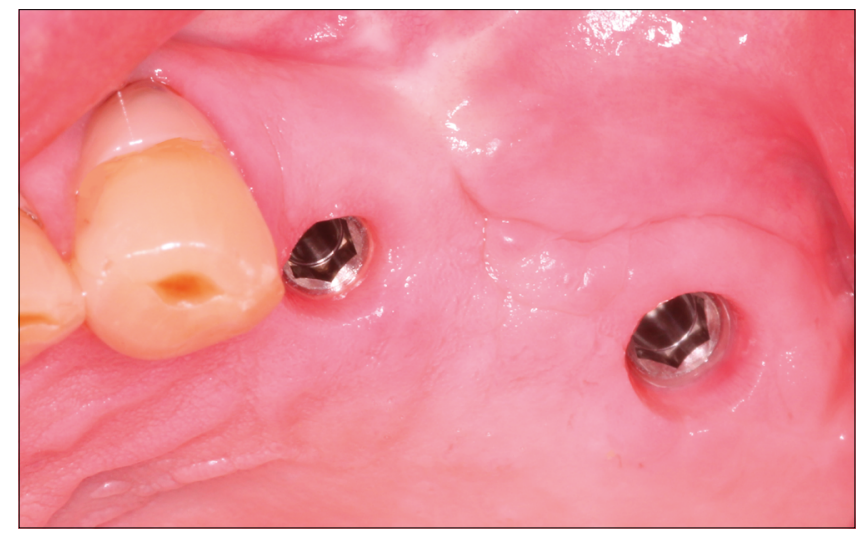

1. kép: A DenTi Root Form implantátumában a belső hatlapos illeszkedést a cilindrikus, ún. „cső a csőben” kapcsolat teszi ellenállóbbá a laterális terhelésekkel szemben

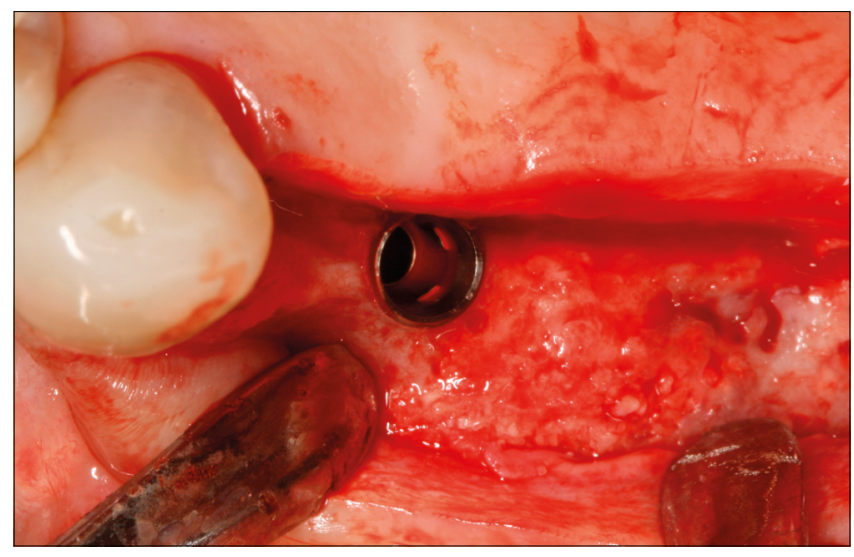

2. kép: A Straumann cég CrossFit rendszerrel kapcsolódó Narrow Neck implantátuma. A rendszer a $15^{\circ}$-os kúp és a nyolcszöges elfordulásgátló (négy egymással szemközti „groove”) előnyeit ötvözi

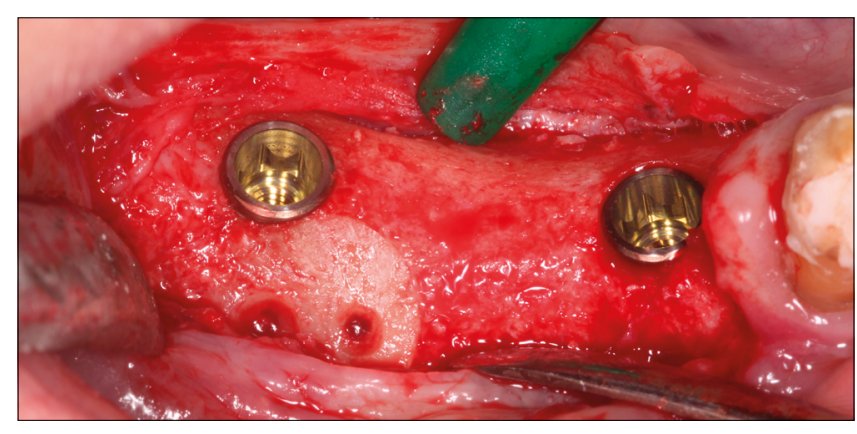

3. kép: A Nobel Parallel rendszerében a kónuszos kapcsolat egy hatszöges struktúrával egészül ki

hoz való információátvitelhez [11]. A cég másik belső, szintén nyolcszöges geometriát képviselő kapcsolata a korábban már említett CrossFit kialakítás. Ez egy $15^{\circ}$-os kúpot ötvöz a négy barázda (groove) által kialakított elfordulásgátlóval (2. kép).

A Nobel Parallel implantátum rendszerben a belső nyolcszög helyett hatszöggel egészül ki a kónuszos struktúra (3. kép). 
Hagyományos $8^{\circ}$-os kónuszos kapcsolat is megtalálható még a piacon, a teljesség igénye nélkül néhány forgalmazó: Avana, 3i, Ankylos.

$11,5^{\circ}$-os Morse kúpos implantátumot az Astra Tech által piacra dobott rendszerekben találhatunk. A kónuszos kialakítás tömíti a két felszín közti virtuális ürt, és csökkenti a mikromozgásokat, illetve a bakteriális szivárgást.

1,5-os Morse kúpos implantátum a Bicon implantátumoknál elérhető, ez nem átmenő csavarral rögzíthető, hanem az egyrészes implantátumfejet kell az endostruktúrába csavarni. Így alakul ki a „friction-fit” és a „cold welding" a felszíni oxidrétegek áttörésével [30].

\section{A kapcsolat jelentősége. Hibaforrások}

A kezdeti hibák kiküszöbölésére a cégek számos implantációs rendszert fejlesztettek. Ezeket a komplikációkat fontos ismernünk, így fel tudunk rá készülni, kontrollálni tudjuk, ráadásul a megfelelő indikációhoz megfelelő implantátumrendszert tudunk választani.

\section{Hibás pozicionálás}

Hibás pozicionálás esetén az implantátum és a felépítmény között nem megfelelő az illeszkedés. Ez a forgási szabadság a csavarlazuláshoz is hozzájárul és terhelés közben mikromozgásokhoz is vezethet. Ráadásul abban az esetben, ha a komponensek nem ülnek megfelelően egymáson, akkor a csavar meghúzása károsíthatja az implantátumtestben lévő meneteket, de akár még a csavar meneteit is. Így vagy úgy, de az implantátumfej endostruktúrához viszonyított hibás pozíciója csavarlazuláshoz vezet.

Tanulmányok kimutatták, hogy általánosságban a $2^{\circ}$ nál kisebb elfordulásból adódó pontatlan illeszkedés még stabil csavarkapcsolatot biztosít, ami korlátozza annak meglazulását. A hagyományos külső hatszögkapcsolatban a hibás illeszkedés $3-10^{\circ}$-os volt, a hatszög magasításával és szélesítésével ez csökkent. A hatszög kónuszos struktúrával való kiegészülése nyomán, illetve a belső kónuszos kapcsolatok megjelenésével a jelenség kiküszöbölődött, korlátozva a mikromozgás és a csavarlazulás incidenciáját is [31].

\section{Csavarlazulás}

A csavarlazulás az egyik leggyakoribb komplikáció, amivel a fogászati implantológiában találkozhatunk [12].

A kilazult csavarnak szignifikánsan nagyobb esélye van a törésre. Több ok is ismert, amely csavarlazulást idézhet elő. Ezek között lehet az orvos hibájából adó- dó: nem kellően meghúzott csavar, inadekvát fogpótlás. Az alábbi egyéb okok is csavarlazuláshoz vezetnek: a komponensek rossz illeszkedése, csavarfáradás, a csont rugalmasságából adódó mozgás, túlterhelt pótlás [6].

A külső hatszöges kapcsolatoknál a tanulmányok 6-48\%-ban megjelenő csavarlazulásról számoltak be, ehhez képest a belső kónuszos kapcsolatú implantátumrendszereknél ez csak 3,5\% volt, ami jelentős fejlödésnek mondható [22].

\section{Erőeloszlás}

Belső kapcsolatos implantátumokál a leggyengébb láncszem az implantátum-felépítmény-csavar-csont tengelyből maga a csont, mert a tehereloszlás ilyenkor mélyen az implantátum falában összpontosul, és adódik tovább onnan a csont felé. Ez a fajta erőeloszlás kivédi a csavarra irányuló erőket, így tehát jelentősen lecsökkenti a csavarlazulás incidenciáját.

A belső kapcsolatok mély illeszkedése sokkal ellenállóbb a hajlító erőkkel szemben, mint a sekélyebb hagyományos külső hatszöges struktúrák, ez főleg a moláris régióban lévő nagyobb teherbírást igénylő pótlásoknál fontos [28].

Ugyanakkor egyes szerzők ezt a fajta terheléseloszlást nem feltétlenül tartják előnyösnek. A csavaron jelentkező kisebb terhelés a csonton manifesztálódó nagyobb igénybevétel árán valósul meg, amely kresztális csontvesztést okozhat. A hagyományos külső hatszöges struktúráknál például kényelmetlen, de könnyebben kiküszöbölhető komplikáció a csavarlazulás, amit a traumás okklúzió megszüntetésével, folyamatos kontrollal és a csavarok újrahúzásával orvosolunk, a csont jelentősebb terhelését és az esetleges csontvesztést csökkentve [31].

\section{Csavartörés}

A protetikai csavar törése korábban az egyik leggyakoribb komplikációként volt számontartva a fogászati implantológiában [16, 17]. A csavartörés előfordulását ötéves periódusban 3,9\%-nak írták le [21]. Leggyakrabban megemlített oka a protetikai csavar törésének a pótlás nem adekvát, vagy túl nagy terhelése, a csavarlazulás és az implantátum komponenseire ható erők kedvezőtlen iránya $[10,14]$. Általában a csavar törésének oka anyaghibából adódik. Gyakran a csavar az implantátum vagy a szuprastruktúra mindenféle irreverzibilis károsodását megelőzően törik, így egyfajta biztosítékként funkcionál, ami még akkor jelzi a bajt, amikor az egyéb struktúrák károsodása minimális, viszszafordítható. A hiba legvalószínúbb okát ilyenkor ki kell javítani, hogy megelőzzük a későbbi csavarlazulást vagy törést [14]. 


\section{Elfordulásgátlás}

Az elfordulásgátlás koncepciójának két gyakorlati haszna is van. Az első, hogy a behelyezett implantátum nem tud a tengelye körül elfordulni, és így fix pozícióban marad. Ez egy fog pótlásakor rendkívül előnyös. Erre alkalmas lehet valamilyen szöggel rendelkező geometriai struktúra, de a kónuszos csatlakozás szoros kapcsolata miatt létrejövő súrlódásos illeszkedés is rendelkezik elfordulásgátló funkcióval. A második előnyt csak a sokszöges kapcsolatokkal rendelkező struktúráknál figyelhetjük meg, mégpedig azt, hogy a felépítmény kicsavarása és eltávolítása után könnyen visszahelyezhető ugyanabba a pozícióba, míg ez a kúpos kapcsolatoknál nem tehető meg teljes biztonsággal. Így a protetikai rendszer és az információ laborba küldése is jóval egyszerübb. Ha valamilyen okból hozzá akarunk férni az implantátum testéhez - legyen az átöblítés, egy egyszerủ kontrollvizsgálat, vagy ha az implantátumfejet szeretnénk módosítani - könnyen megtehetjük, hiszen biztosan megtaláljuk visszahelyezéskor az implantátumfej eredeti pozícióját [11, 35].

Tanulmányok kimutatták, hogy elfordulásgátló nélküli rendszerekben ezen hiányosság miatt megnyílnak a kontaktpontok az implantátum felépítménye és a környező fogak közt, így mindenképpen megfontolandó, hogy az általunk kiválasztott rendszer rendelkezzen ilyen struktúrával [18, 34].

\section{Implantátum és implantátumfej közötti mikromozgás}

Köztudott, hogy gyógyulási fázisban az implantátum csontban való minimális amplitudójú (150 mikrométernél nagyobb) mozgása is az osszeointegráció elmaradásához vagy elégtelen kialakulásához vezethet [20, 32].

Ugyanakkor az implantátum és az implatátumfej közötti biztos kapcsolat hiányában a két komponens közt is lehet mikromozgás, ami a pótlás szempontjából rendkívül hátrányos [35]. Bármiféle mozgás a kapcsolódó részek közt káros lehet a csavarra, ennek hatására mikrorések keletkezhetnek, ami további kockázatokat jelent a rendszer egészére nézve. Ezt a fajta mikromozgást kapcsolatba hozták már különböző mechanikai hibákkal, csavarlazulással, alkotórészek törésével, anyagfáradással, de még periimplantáris betegséggel is. A mikromozgás hatására képződő mikrorésbe baktériumok juthatnak, majd az implantátum belsejében tovább szaporodó mikroorganizmusok a mikromozgás hatására kipréselődhetnek a periimplantáris térbe. Ezt a jelenséget szemléletesen mikropumpának hívják.

A mikromozgás megelőzésére szoros illeszkedésű kapcsolatot kell kialakítani jó tehereloszlással, és meg kell védeni a rendszert a túlterhelődéstől [23].

\section{Bakteriális zárás, bakteriális szivárgás}

Az implantátum-felépítmények eltávolításakor sok esetben kellemetlen szagokat érezhetünk. Ennek magyarázata az, hogy az implantátum és a felépítmény közti mikrorésekbe nyál és baktériumok szivárognak, teret biztosítva a mikroorganizmusok elszaporodásának [2]. A kevert baktériumpopuláció a junkciónál levő gyulladást is erősíti, ami végső soron kresztális csontfelszívódást eredményez.

A belső kapcsolatok precíz, szoros illeszkedésüknek köszönhetően nagyobb eséllyel alakítanak ki megfelelő bakteriális zárást a komponensek közt, mint a külső kapcsolatok. A legtöbb belső kapcsolatú modell bakteriális zárást biztosító háttértanulmányokkal kerül forgalomba. llyen például a Bicon tanulmánya, ami szerint belső kúpos kapcsolatuk egyáltalán nem enged sem kifelé, sem befelé irányuló szivárgást, vagy az Ankylos vizsgálata, ami pedig 60 órán keresztüli vákuum-zárásról biztosít $[8,25]$.

\section{Periimplantitisz}

Mint ahogy a természetes fogazatban a pellikula, majd a biofilm kialakulása, később a kiváltott gyulladás megjelenése a dentális implantátumoknál is megfigyelhető. Ez a folyamat potenciálisan okozhatja a periimplantáris zárás és csontállomány apikális migrációját. A periimplantitisz megjelenése jóval gyakoribb az orális implantátumoknál, mint a parodontális betegségek előfordulása a természetes fogazatban. Ez azért lehetséges, mert az implantátum körüli nyálkahártya-zárás nem annyira hatásos, mint a természetes fogakat körülvevő gingivális zárás [31]. Ennek a zárásnak a kialakulása, fenntartása, az implantátumfej és a lágyszövetek egymásra hatása, kapcsolata fontos szempont.

Az implantátum körüli gyulladást és a kresztális csontfelszívódást a platform switching eljárással is csökkenthetjük [1, 24, 31]. Ilyenkor az implantátumfej átmérője keskenyebb, mint az implantátum átmérője. Ez a lehetőség a belső- és külső kapcsolatos rendszereknél is adott, bár a belső kialakítású kapcsolatok jóval gyakrabban alkalmazzák. A Straumann, az Ankylos, a Bicon és az Astra rendszereivel kezdetektől fogva működőképes ez a koncepció.

Mikor az implantátum körüli szövetek biológiai válaszairól esik szó, beszélni kell az idegen anyagok által kiváltott gyulladásokról is. Például ebben a térben megjelenő cementfelesleg a periimplantitisz megjelenésének és az implantátum elvesztésének egyik lehetséges oka [36, 37].

\section{Esztétikai jelentőség}

Esztétikai zónában készítendő restaurációnál a fogpótlás bukkális részének elegendő vastagságú kerámiából 
kell állnia, hogy ideális esztétikai eredményt érjünk el. Továbbá egy esztétikailag kielégítő fogpótlás megköveteli azt, hogy az implantátum - felépítmény - kapcsolat a marginális gingivához viszonyítva minél mélyebbre kerüljön, mindezt természetesen anélkül, hogy az implantátum mellett kialakuló biológiai szélességet megsértenénk, és ezzel következményes kresztális csontfelszívódást idéznénk elő. Ezzel megfelelő emergencia profilt tarthatunk fent, és eltakarhatjuk az esztétikailag hátrányos fémes kapcsolatot.

A külső kapcsolatoknál ahhoz, hogy esztétikailag megfelelő eredményt érhessünk el, sokszor olyan vastag kerámiával kell az implantátumfejet bevonni, hogy a fog túl testes lesz, nem esztétikus emergenciaprofillal. Ezeknél a kapcsolatoknál gyakran kilátszik a szürke fém, tovább rontva az esztétikán.

A belső kapcsolatok tagadhatatlanul előnyösebbek ezekből a szempontokból. Elegendő mennyiségű kerámiát lehet rá felvinni, ugyanakkor esztétikus bukkális kontúrt és megfelelő emergencia profilt lehet elérni alkalmazásukkor [31].

Esztétikai kérdés még ugyanakkor, hogy a restaurátum milyen módon rögzül a protetikai mücsonkhoz. A szögeltéréssel kapcsolatos implantációs problémákra - főleg a magas esztétikájú területeken, mint a felső frontok - a legtöbb implantációs rendszer továbbra is a cementezett pótlásokkal biztosítja a megoldást. Ezekben az esetekben ugyanakkor egy belső kapcsolatos struktúra valódi alternatívát nyújthat a cementezett restaurációnak. A szögtört implantátumfejek lehetővé teszik a tengelyállás kiküszöbölését $25^{\circ}$-ig anélkül, hogy a csavar feje látható helyre (labiálisan) kerülne [15].

Például a Nobel Biocare szögtört rendszere úgy kombinálja a szövetbarát és esztétikus cirkonfejet egy titánbázissal, hogy mindkettő csavaros kapcsolattal rögzíthető [31].

Ugyanakkor azt is észre kell vennünk, hogy bármenynyire orálisan is helyezzük el a restaurátumon a csavarhoz vezető bemeneti nyílást, az azt fedő tömőanyag esztétikailag kedvezőtlen lehet.

\section{Összefoglalás}

Brånemark eredeti, külső hatszöges implantátuma és az azon rögzülő merev öntvény kiváló alternatíva a fogatlan páciensek ellátására. Az indikációk kiszélesedésével azonban szükséges lett a hagyományos külső hatszög-konstrukció módosítása, illetve a belső kapcsolatok kifejlesztése. Az új indikációkban jelentkező csavarlazulás és törés fokozott incidenciáját a módosításokkal csökkentették, a belső kapcsolatok bevezetésével pedig elhanyagolhatóvá váltak. A külső kapcsolatok mikromozgása jelentős, és mikrorések is gyakrabban fordulnak elő a komponensek között, így bakteriális zárásuk kevésbé kielégítő. A legjobb mechanikai és biológiai zárást a kúpos struktúrákkal lehet elérni. A kizárólag kúpos struktúrák nem rendelkez- nek elfordulásgátló tulajdonsággal, ehhez valamilyen sokszögnek, vagy horonynak a rendszerbe illesztésére van szükség. Ilyenek például a passzív illeszkedésű 6 pontos-, 12 pontos-, 3 pontos belső kapcsolatok, de a hatszöggel vagy nyolcszöggel kiegészített kúpok is megfelelnek erre a célra. Ezek a struktúrák rendkívül előnyösek szóló foghiányok, vagy szögtört implantátumfejek alkalmazásakor. A belső kapcsolatok erőeloszlása a csavarra és az implantátumra nézve kedvezőbb, viszont a csont nagyobb terhelésben részesül, mint a külső kapcsolatoknál, így ezt is mérlegelnünk kell, amikor választásra kerül a sor. Esztétikai szempontból a belső kapcsolatok sokkal kedvezőbb eredményt nyújtanak mind emergencia-profil, mind a pótlás anatómiai pontossága, mind a fémek esetleges láthatóvá válásának tekintetében.

\section{Irodalom}

1. Atieh MA, Ibrahim HM, Atieh AH: Platform switching for marginal bone preservation around dental implants: a systematic review and meta-analysis. Journal of periodontology 2010; 81 (10): 1350-1366. https://doi.org/10.1902/jop.2010.100232

2. Baggi LDGM, Mirisola C, Calcaterra R: Microbiological evaluation of bacterial and mycotic seal in implant systems with different implant-abutment interfaces and closing torque values. Implant Dent 2013; 22 (4): 344-350. https://doi.org/10.1097/ID.0b013e 3182943062

3. BARZILAY: Rotational accuracy of implant components for singletooth, root-form implants. Dental implantology update 1991; 2 (1): 5.

4. BINON PP: Implants and components: entering the new millennium. The International journal of oral \& maxillofacial implants 2000; 15: 76-94.

5. BINON PP: The spline implant: design, engineering, and evaluation. International Journal of Prosthodontics 1996; 9 (5). https:// doi.org/10.1097/00008505-199600540-00009

6. BINON PP, MchuGH M: The effect of eliminating implant/abutment rotational misfit on screw joint stability. International Journal of Prosthodontics 1996; 9 (6).

7. Cordaro L, Torsello F, Mirisola Di Torresanto V, Rossini C: Retrospective evaluation of mandibular incisor replacement with narrow neck implants. Clinical oral implants research 2006; 17 (6): 730-735. https://doi.org/10.1111/j.1600-0501.2006.01276.x

8. Dibart S, Warbington M, Su M F, Skobe Z: In vitro evaluation of the implant-abutment bacterial seal: the locking taper system. The International journal of oral \& maxillofacial implants 2005; 20 (5): 732-737.

9. Ding TA, Woody RD, Higginbottom FL, Miller BH: Evaluation of the ITI Morse taper implant/abutment design with an internal modification. International Journal of Oral Maxillofacial Implants 2003; 18 (6).

10. DivinYı T: Implantációs fogpótlások a fogorvosi gyakorlatban. Springer Kiadó, Budapest, 2002.

11. DivinYI T: Orális implantológia. Semmelweis Kiadó, Budapest, 2007.

12. Ekfeldt A, Carlsson GE, BörJesson G: Clinical evaluation of single-tooth restorations supported by osseointegrated implants: a retrospective study. International Journal of Oral Maxillofacial Implants 1994; 9 (2).

13. ENGLISH C E: Externally hexed implants, abutments, and transfer devices: a comprehensive overview. Implant dentistry 1992; 1 (4): 273-282. https://doi.org/10.1097/00008505-199200140-00009

14. Francis L, Zeenath H, Lylajam S, Harshakumar K: Implant screw fracture. Journal of Dental Implants 2013; 3 (2): 181. https://doi. org/10.4103/0974-6781.118868

15. Garcia-Gazaui S, Razzoog M, Sierraalta M, Saglik B: Fabrication 
of a screw-retained restoration avoiding the facial access hole: a clinical report. The Journal of prosthetic dentistry 2015; 114 (5): 621-624. https://doi.org/10.1016/j.prosdent.2015.06.007

16. Goodacre CJ, Bernal G, Rungcharassaeng K, Kan JY: Clinical complications with implants and implant prostheses. The Journal of prosthetic dentistry 2003; 90 (2): 121-132. https://doi.org/10. 1016/S0022-3913(03)00212-9

17. Goodacre CJ, Kan JY, Rungcharassaeng K: Clinical complications of osseointegrated implants. The Journal of prosthetic dentistry 1999; 81 (5): 537-552. https://doi.org/10.1016/S0022-3913(99) 70208-8

18. Greenstein G, Carpentieri J, Cavallaro J: Open contacts adjacent to dental implant restorations: Etiology, incidence, consequences, and correction. The Journal of the American Dental Association 2016; 147 (1): 28-34. https://doi.org/10.1016/j.adaj.2015. 06.011

19. Jing L, XIN X, Guangshui J, Yanjin G, HaiYun H, Jin L, et al: Threedimension finite element analyses of interior stress of two kinds of Replace implant. West China Journal of Stomatology 2011; 29 (5). https://doi.org/10.1155/2016/4867402

20. Kawahara $\mathrm{H}$, Kawahara D, Hayakawa M, Tamal $\mathrm{Y}$, Kuremoto $T$, MATSUDA S: Osseointegration under immediate loading: biomechanical stress-strain and bone formation-resorption. Implant dentistry 2003; 12 (1): 61-68. https://doi.org/10.1097/01.ID. 0000034394.75768.E3

21. Kreissl ME, Gerds T, Muche R, Heydecke G, Strub JR: Technical complications of implant-supported fixed partial dentures in partially edentulous cases after an average observation period of 5 years. Clinical oral implants research 2007; 18 (6): 720-726. https://doi.org/10.1111/j.1600-0501.2007.01414.x

22. Levine RA, Clem D, Wilson T, Higgibottom F, Solnit G: Multicenter Retrospective Analysis of the ITI Implant System Used for SingleTooth Replacements: Results of Loading for 2 or Mare Years. International Journal of Oral Maxillofacial Implants 1999; 14: 516-520.

23. LIU Y, WANG J: Influences of microgap and micromotion of implant-abutment interface on marginal bone loss around implant neck. Archives of Oral Biology 2017; 83: 153-160. https://doi.org/ 10.1016/j.archoralbio.2017.07.022

24. Maeda Y, Horisaka M, YaGI K: Biomechanical rationale for a single implant-retained mandibular overdenture: an in vitro study. Clinical oral implants research 2008; 19 (3): 271-275. https://doi. org/10.1111/j.1600-0501.2007.01425.x

25. MaIRgünther RN, G: Das Dichtigkeits-verhalten des Verbindungssystems beim zweiphasigen Ankylos-Implantat [The tightness behavior of the connection system of the 2-phase Anky- los implant]. Zeitschrift für Zahnärztliche Implantologie 1992; 5: 50-53.

26. Meng JC, Everts JE, Qian F, Gratton DG: Influence of connection geometry on dynamic micromotion at the implant-abutment interface. International Journal of Prosthodontics 2007; 20 (6)

27. Merz BR, Hunenbart S, Belser UC: Mechanics of the implantabutment connection: an 8-degree taper compared to a butt joint connection. International Journal of Oral Maxillofacial Implants 2000; 15 (4).

28. Möllersten L, Lockowandt P, Lindén L-Å: Comparison of strength and failure mode of seven implant systems: an in vitro test. The Journal of prosthetic dentistry 1997; 78 (6): 582-591. https://doi. org/10.1016/S0022-3913(97)70009-X

29. Nevins M, LANGER B: The successful application of osseointegrated implants to the posterior jaw: a long-term retrospective study. International Journal of Oral Maxillofacial Implants 1993; 8 (4).

30. Prithviraj D, Muley N, Gupta V: The evolution of external and internal implant-abutment connections: A review. International Dental Research 2012; 2 (2): 37-42. https://doi.org/10.5577/ intdentres.2012.vol2.no2.3

31. ShAFIE HR: Clinical and laboratory manual of dental implant abutments: John Wiley \& Sons, 2014. https://doi.org/10.1002/ 9781118928547

32. Szmukler-Moncler S, Salama H, Reingewirtz $Y$, Dubruille J: Timing of loading and effect of micromotion on bone-dental implant interface: review of experimental literature. Journal of biomedical materials research 1998; 43 (2): 192-203. https://doi. org/10.1002/(SICI)1097-4636(199822)43:2<192::AID-JBM14>3. $0 . \mathrm{CO} ; 2-\mathrm{K}$

33. Tang C-B, Liu S-Y, Zhou G-X, Yu J-H, Zhang G-D, BaO Y-D, et al: Nonlinear finite element analysis of three implant-abutment interface designs. International journal of oral science 2012; 4 (2): 101. https://doi.org/10.1038/ijos.2012.35

34. Varthis S, Randi A, TaRnow DP: Prevalence of Interproximal Open Contacts Between Single-Implant Restorations and Adjacent Teeth. International Journal of Oral Maxillofacial Implants 2016; 31 (5). https://doi.org/10.11607/jomi.4432

35. WADHWANI C: Understanding implant abutment connection interfaces. Decisions in Dentistry 2018: 31-34.

36. WadhwanI CPK: Cementation in Dental Implantology. SpringerVerlag Berlin Heidelberg, Berlin, 2015. https://doi.org/10.1007/ 978-3-642-55163-5

37. WILSON TG, JR: The positive relationship between excess cement and peri-implant disease: a prospective clinical endoscopic study. Journal of periodontology 2009; 80 (9): 1388-1392. https:// doi.org/10.1902/jop.2009.090115 


\author{
Kerkovits B, CZinkóczky B, Kivovics M
}

\title{
Implant-abutment connection types in dental implant systems
}

Review

It is difficult for clinical dentists to keep up with the rapid development of dental implant systems. The surgical issues of implantation are mostly clarified, and no surgical revolution is expected in the near future. However, the implant-abutment connection (IAC) types are permanently being modified. Advantages and disadvantages of the most important IACs - external hex, tapered hex, external octagon, spline implant, 3-point internal tripod, 6-point internal hex, internal octagon, 12-point internal hex, Morse taper - are discussed and biological, mechanical and aesthetic aspects of IACs are detailed in the article. The article can serve as a guide to decide which connection type to use in a certain indication. Following Brånemark's protocol, original external hexagonal implants are excellent alternatives for the treatment of anodontous patients. However, as the indications were broadened, it became necessary to modify the traditional external hexagon design, and to develop the internal connections. The increased incidence of screw loosening and fracture in the new indications has been significantly reduced by the modifications and the introduction of internal connections. In external connections the micro-motion and microleakage are more common between the components, that is why bacterial seal is less satisfactory. Conical structures provide the best mechanical and biological seal. Conical structures do not have anti-rotation properties, and therefore the insertion of a polygon or spline into the system is required. The 6-point, 12-point, 3-point internal connections are suitable for this purpose, as are Morse tapers supplemented by hexagonal or octagonal structures. In the case of angled abutments or single missing tooth is being replaced these structures are recommended. The force distribution of the internal connections is more favourable for the screw and the implant body, but it is unfavourable to the bone. In contrast to the external connections, the load on the bone is less, so this must also be considered when choosing the most suitable type. From the aesthetic point of view, internal connections provide much better results in terms of the emergence profile, the anatomical accuracy of the replacement, and the potential exposure of the metal parts.

Keywords: Dental implants, Dental Implantation, Endosseous, Aesthetic, Dental Implant-Abutment Design, Peri-Implantitis 